\title{
Mobile Munsell Soil Color Chart Berbasis Android Menggunakan Histogram Ruang Citra HVC dengan Klasifikasi KNN
}

\author{
Android-Based Mobile Munsell Soil Color Chart by Using HVC \\ Color Model Histogram with KNN Classification
}

\author{
KARLISA PRIANDANA ${ }^{1}$, AHMAD ZULFIKAR $\mathrm{S}^{* 1}$, SUKARMAN $^{2}$
}

\begin{abstract}
Abstrak
Penentuan warna tanah tidak mudah karena banyaknya jenis tanah dan tingginya tingkat kemiripan warna tanah. Untuk mengatasi kesulitan ini, para praktisi menggunakan suatu buku pedoman warna tanah yaitu Munsell soil color chart (MSCC). Penelitian ini bertujuan mengembangkan aplikasi mobile untuk mengidentifikasi warna tanah dalam menentukan warna mayor tanah sesuai buku MSCC. Aplikasi dibangun menggunakan pemodelan warna HVC dengan komponen warna hue, value, dan chroma. Penelitian ini menekankan klasifikasi untuk warna hue saja. Meskipun demikian, diteliti juga komponen warna value dan chroma. Citra yang digunakan sebagai data latih adalah 259 citra dari buku MSCC yang masing-masing berukuran 1600 piksel. Data warna hue dari setiap piksel ini dianalisis dalam bentuk histogram dan diklasifikasikan dengan KNN. Hasil penelitian menunjukkan bahwa akurasi tertinggi dalam klasifikasi nilai hue adalah $45 \%$ pada nilai $k=5$. Akurasi mungkin dapat ditingkatkan dengan cara menggunakan data soil color yang sudah tersedia secara online.
\end{abstract}

Kata kunci: Android, HVC, KNN, Munsell soil color chart.

\begin{abstract}
Soil color determination is a challenging task because of the various types of soil and the high similarity of soil color. Munsell soil color chart (MSCC) is used to overcome this issue. The purpose of this research is to develop an Android-based mobile application to identify the major color of soil according to MSCC. The application utilized HVC color model with hue, value, and chroma color components. The hue color component had been the main concern of this research, although the value and chroma color components were also observed. The training data were 259 images from MSCC, with 1600 pixels each. Hue color data from these pixels were analyzed in the form of histogram and classified with KNN. The results showed that the highest classification accuracy of hue value was $45 \%$ at $k=5$. This accuracy might be improved by utilizing the soil color data that are available online.
\end{abstract}

Keyword: Android, HVC, KNN, Munsell soil color chart.

\section{PENDAHULUAN}

Tanah sangat penting untuk mendukung kehidupan tumbuhan dengan menyediakan unsur hara dan air serta sebagai penopang akar. Di dalam tanah, terdapat berbagai unsur hara atau partikel yang sangat berperan penting bagi kelangsungan hidup tanaman, seperti kandungan bahan organik, kondisi drainase, dan aerasi (Soepardi 1983). Warna tanah sering digunakan sebagai salah satu parameter untuk mengklasifikasikan tanah. Hasil klasifikasi tanah selanjutnya digunakan sebagai dasar penilaian kesesuaian lahan berbagai tanaman pertanian maupun tanaman kehutanan.

\footnotetext{
${ }^{1}$ Departemen Ilmu Komputer, Institut Pertanian Bogor, Bogor 16680

${ }^{2}$ Balai Besar Litbang Sumberdaya Lahan Pertanian, Kementerian Pertanian 16114

"Penulis Korespondensi: Tel/Faks: 0251-8625584; Surel: possaidon47@ gmail.com
} 
Dalam penelitian sumberdaya tanah saat ini, Munsell soil color chart (MSCC) digunakan sebagai standar: warna dasar atau warna matriks dan warna karatan sebagai hasil dari proses oksidasi dan reduksi di dalam tanah (Balai Penelitian Tanah 2004). Cara penggunaan MSCC adalah dengan mengecek kemiripan warna tanah pada pedoman warna yang terdapat dalam MSCC. Selama penggunaannya, buku tersebut perlu dibawa ke lapangan untuk dijadikan pedoman dalam mencocokkan warna tanah. Namun, apabila penetapan warna ini dilakukan secara manual, sangat mungkin terjadi kesalahan sehingga informasi yang diperoleh kurang akurat. Selain itu, pengukuran dengan buku MSCC secara langsung di lapangan membuat buku MSCC tersebut cepat rusak, sementara harganya sangat mahal. Berkaitan dengan hal tersebut, maka diperlukan alternatif lain untuk dapat mengukur warna tanah dengan lebih akurat, aman, dan praktis.

Saat ini, belum tersedia aplikasi mobile untuk mendeteksi warna tanah secara otomatis berdasarkan buku MSCC. Berdasarkan permasalahan tersebut, maka penelitian ini bertujuan untuk mengembangkan suatu aplikasi mobile berbasis Android yang dapat mengklasifikasikan warna tanah berdasarkan MSCC secara otomatis. Hasil penelitian ini diharapkan dapat mengurangi kemungkinan kesalahan pencocokan warna tanah, serta mempermudah pengguna MSCC dalam mengklasifikasikan warna tanah.

Teknologi mobile device berbasis Android berkembang sangat pesat sehingga memotivasi para pengembang untuk membuat berbagai aplikasi yang dapat mempermudah aktivitas dan pekerjaan sehari-hari. Menurut data yang dikeluarkan oleh International Data Corporation pada tahun 2012, sistem operasi Android menguasai sekitar 52\% dari total smartphone yang dipakai oleh masyarakat Indonesia (Wahyudi 2012). Oleh karena itu, dalam penelitian ini, aplikasi akan dibangun dengan menggunakan sistem operasi Android.

Pada buku MSCC (Munsell 2009), dijelaskan bahwa terdapat tiga variabel penting pada warna tanah seperti: hue, value, dan chroma (HVC). Berdasarkan hal tersebut, maka fitur warna tanah yang akan diekstraksi pada aplikasi yang dibuat adalah fitur warna pada ruang citra hue, value, dan chroma (HVC). Hue adalah warna spektrum yang dominan sesuai dengan panjang gelombangnya, value menunjukkan gelap terangnya warna sesuai dengan banyaknya sinar yang dipantulkan, dan chroma menunjukkan kemurnian atau kekuatan dari warna spektrum. Chroma didefinisikan juga sebagai gradasi kemurnian dari warna atau derajat pembeda adanya perubahan warna dari kelabu atau putih netral ke warna lainnya.

Menurut Boiman et al. (2008) metode klasifikasi k-nearest neighbor (KNN) sangat sederhana, efisien, dan kinerjanya sangat baik dalam klasifikasi citra. Oleh karena itu, untuk mengklasifikasikan skala warna tanah pada perangkat mobile, akan digunakan warna mayor pada tanah dengan klasifikasi KNN.

Data uji dan data latih yang digunakan adalah data foto yang diperoleh dari buku MSCC milik Balai Besar Penelitian dan Pengembangan Sumberdaya Lahan Pertanian (BBSDLP), Kementerian Pertanian. Pengambilan citra dilakukan pada keadaan cerah pada pukul 08.00 sampai 11.00. Kamera yang digunakan adalah kamera dari perangkat mobile dengan resolusi 8 megapiksel. Penelitian difokuskan pada model warna hue dengan menampilkan warna dominan saja.

\section{TINJAUAN PUSTAKA}

\section{Warna Tanah dan Karatan}

Menurut Hardjowigeno (1985), "warna tanah merupakan sifat morfologi yang paling mudah dibedakan. Warna merupakan petunjuk untuk beberapa sifat tanah, misalnya: warna hitam menunjukkan kandungan bahan organik tinggi. Warna merah menunjukkan adanya oksidasi bebas (tanah-tanah yang teroksidasi). Warna abu-abu atau kebiruan menunjukkan adanya reduksi". 
Perlu diketahui bahwa hubungan antara warna tanah dengan kandungan bahan organik di daerah tropika banyak yang tidak sesuai dengan yang ditemukan di benua Amerika atau Eropa atau daerah beriklim sedang. Misal, tanah-tanah merah di Indonesia banyak yang mempunyai bahan organik lebih dari satu persen, sama dengan kandungan organik tanah hitam di daerah-daerah yang beriklim sedang. Menurut Hardjowigeno (1985), selain warna tanah, karatan tanah juga perlu dipelajari lebih lanjut khususnya penyifatan tanah yang meliputi jumlah, ukuran, dan bandingan (kontras).

Merujuk buku MSCC, penentuan nilai hue dimulai dari spektrum dominan paling merah (5R) sampai spektrum dominan paling kuning (5Y). Selain itu, di dalam beberapa buku MSCC sering terdapat juga spektrum untuk warna-warna tanah tereduksi (gley). Value tanah bernilai antara 2-8. Semakin tinggi nilai value, maka warna tanah makin terang, yang menandakan bahwa jumlah sinar yang dapat dipantulkan oleh tanah tersebut semakin banyak. Nilai value pada lembar buku MSCC terbentang secara vertikal dari bawah ke atas dengan angka 2 menunjukkan warna paling gelap dan angka 8 menunjukkan warna paling terang. Nilai chroma tanah pada lembar buku MSCC dibagi dengan rentang 1-8. nilai chroma yang tinggi menunjukkan kemurnian spektrum atau kekuatan warna spektrum yang makin meningkat dan begitu pula sebaliknya.

\section{Model Warna}

Suatu warna didasarkan pada perbedaan eksitasi dari 3 penerima cahaya di dalam retina. Ketiga warna tersebut adalah merah, hijau, dan biru (RGB) yang akan menentukan warna dari suatu obyek (Ford dan Roberts 1998). Nilai hue, saturation, dan value (HSV) dapat diperoleh dari nilai model warna RGB (Acharya dan Ray 2005). Dari model warna tersebut, dapat pula diperoleh nilai $C$ (chroma) melalui persamaan berikut.

$$
\begin{aligned}
& R=\frac{R}{255} ; G=\frac{G}{255} ; B=\frac{B}{255} \\
& H^{\prime}= \begin{cases}\text { tidak terdefinisi, } C=0 \\
\frac{G-B}{C} \bmod 6 & , M=R \\
\frac{B-R}{C}+2 & , M=G \\
\frac{R-G}{C} & , M=B\end{cases} \\
& H=60^{\circ} \times H^{\prime}, \\
& V=M \quad \begin{array}{c}
0, C=0 \\
C / V, \text { lainnya }
\end{array} \\
& C=S \times V
\end{aligned}
$$

dengan:

$M=\max \{R, G, B\} ; m=\min \{R, G, B\} ; C=M-m$

\section{Metode Klasifikasi $k$-Nearest Neighbor (KNN)}

Konsep dasar metode KNN adalah mencari jarak terdekat antara data uji dengan sejumlah $k$ tetangga terdekat dalam data latih. Berikut langkah-langkah algoritme KNN (Song et al. 2007):

1 menentukan nilai $k$,

2 menghitung jarak antara data uji dengan setiap data latih,

3 mendapatkan $k$ data yang memiliki jarak terdekat,

4 jumlah $k$ data yang memiliki jarak terdekat merupakan kelas yang paling banyak muncul, 
5 kelas yang paling banyak muncul ditentukan sebagai kelas dari data uji.

\section{Jarak Histogram}

Perhitungan jarak antara histogram $A$ dan $B$ dilakukan dengan rumus jarak Euclidean (Gonzales et al. 1987):

dengan:

$$
\mathrm{d}(A, B)=\sqrt{\sum_{j=1}^{n}\left(H_{j}^{A}-H_{j}^{B}\right)^{2}}
$$

$H_{j}^{A}$ : histogram $A$, indeks array ke-j

$H_{j}^{B} \quad$ : histogram $B$, indeks array ke- $j$

$n$ : panjang/rentang histogram

\section{METODE}

\section{Data Penelitian}

Data yang digunakan pada penelitian ini yaitu citra yang diambil dari buku MSCC sebagai data latih dan sebagai data uji yang disediakan oleh Balai Besar Penelitian dan Pengembangan Sumberdaya Lahan Pertanian, Kementerian Pertanian.

\section{Tahapan Penelitian}

Pembuatan aplikasi mobile untuk mengidentifikasi warna tanah berbasis citra diimplementasikan pada mobile device untuk tempat penyimpanan database. Tahapan penelitian mengacu pada penelitian sebelumnya oleh Satyalesmana (2013), seperti yang dapat dilihat pada Gambar 1.

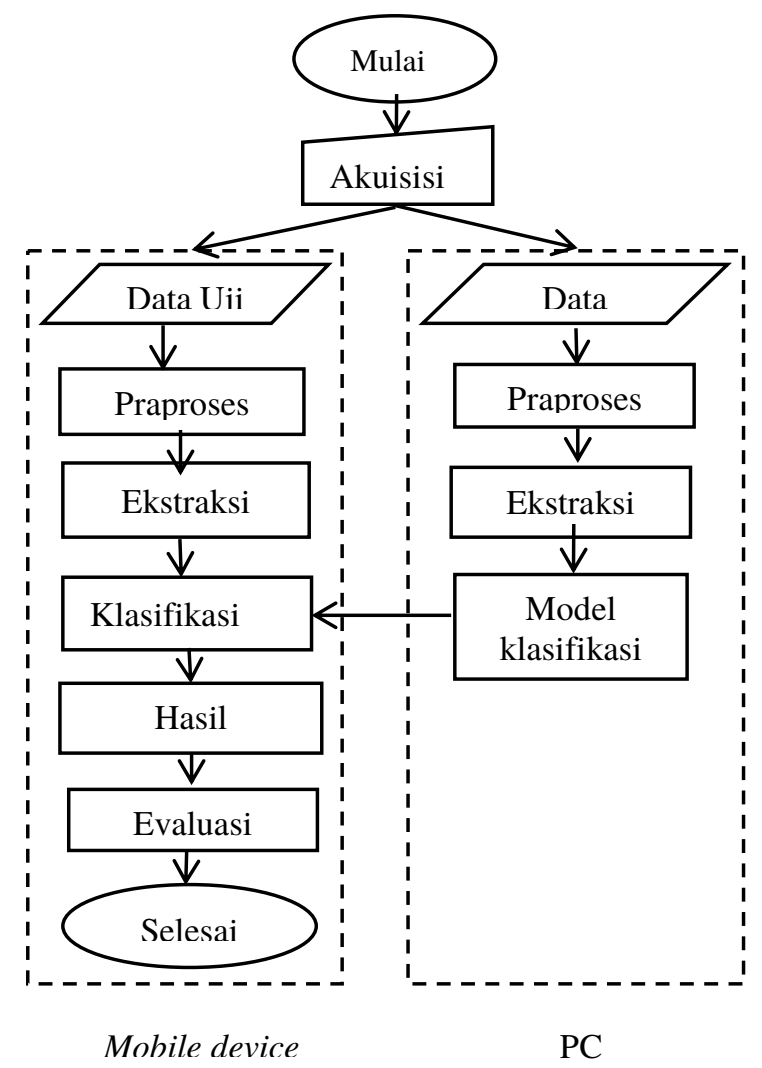

Gambar 1 Metode penelitian 
Tahap awal penelitian merupakan proses akuisisi citra dengan mengambil citra data uji dan data latih. Masukan untuk data uji dan data latih berasal dari buku MSCC. Pembangunan model, klasifikasi dan database histogram dilakukan pada PC untuk kemudian digunakan pada mobile device.

PC

Citra dari buku MSCC akan digunakan untuk pembuatan model. Model dibuat dengan cara melakukan training pada citra. Berikut ini adalah tahapan dalam proses training:

- Akuisisi. Tahap ini dilakukan untuk pengambilan citra digital dari buku MSCC dari Balai Besar Penelitian dan Pengembangan Sumberdaya Lahan Pertanian yang bertujuan guna pembuatan data latih dan data uji citra.

- Praproses. Praproses dilakukan untuk pemotongan citra digital yang bertujuan untuk mengambil bagian citra yang ingin diproses. Proses ini dilakukan untuk menurunkan waktu komputasi dikarenakan citra yang diambil lebih kecil dan bagian yang tidak terkait warna larutan dapat dihilangkan. Tahap praproses data latih dilakukan di PC untuk menghasilkan model klasifikasi yang akan digunakan pada saat implementasi pada aplikasi mobile, sedangkan tahap praproses untuk data uji dilakukan di ponsel pada saat pengujian.

- Ekstraksi Ciri. Tahap ini dilakukan untuk mengambil nilai komponen warna pada setiap citra yang diperoleh dari tahapan praproses. Komponen warna yang diperoleh tersebut merupakan model warna RGB. Untuk memperoleh model warna HVC maka dilakukan konversi warna dari RGB tersebut. Hasil konversi tersebut kemudian ditampilkan dalam histogram dengan mengambil nilai dari setiap piksel dengan rentang 0-255.

- Model Klasifikasi. Klasifikasi dilakukan berdasarkan hasil yang diperoleh dari tahap sebelumnya. Metode klasifikasi yang digunakan adalah membandingkan nilai HVC masing-masing piksel pada data uji dengan nilai HVC pada data latih untuk menemukan nilai histogramnya. Nilai histogram akan diklasifikasi dengan KNN. Perhitungan jarak yang dipakai untuk menentukan jarak antar-histogram adalah jarak Euclidean, yang akan menghitung jarak histogram warna dari citra tanah sebagai data uji dengan setiap 259 histogram warna sebagai data latih yang terdapat pada model klasifikasi. Setelah diperoleh sebanyak $k$ data yang memiliki jarak terdekat, kemudian diketahui kelas yang paling banyak muncul, kelas tersebut adalah kelas dari data uji.

- Pengujian dan Evaluasi. Evaluasi hasil klasifikasi dapat dilakukan dengan cara menghitung tingkat akurasi menggunakan rumus sebagai berikut:

$$
\text { akurasi }=\frac{\sum \text { data uji yang prediksi benar }}{\sum \text { data uji keseluruhan }}
$$

Evaluasi hasil pengujian dilihat dengan menghitung nilai koefisien determinasi $\left(R^{2}\right) . R^{2}$ digunakan untuk mengukur seberapa baik garis regresi yang terbentuk oleh nilai dugaan dengan nilai aktualnya, semakin baik jika mendekati 1 . Menurut Walpole (1992), $R^{2}$ dapat dihitung dengan menggunakan Persamaan 8.

dengan:

$$
R^{2}=\frac{\left[\sum_{i=1}^{n}\left(\hat{y}_{i}-\bar{y}\right)\left(y_{i}-\bar{y}\right)\right]^{2}}{\sum_{i=1}^{n}\left(\hat{v}_{i}-\bar{y}\right)^{2}\left(y_{i}-\bar{y}\right)^{2}}
$$

$y_{i}$ : nilai aktual, $\hat{y}_{i}:$ nilai prediksi, $\bar{y}$ : nilai aktual rata-rata, dan $\overline{\hat{y}}$ : nilai prediksi rata-rata.

\section{Mobile Device}

Mobile device melakukan proses pengenalan citra menggunakan perbandingan nilai HVC antara masing-masing nilai HVC pada data uji dengan nilai HVC data latih. Ketika dijalankan, aplikasi secara otomatis melakukan praproses (cropping) dan proses ekstraksi fitur (pengambilan nilai hue, value, dan chroma). Kemudian, basis data yang diperoleh dari PC 
digunakan untuk membandingkan nilai HVC citra data uji pada mobile dengan nilai HVC pada basisdata.

Alur sistem untuk identifikasi citra pada aplikasi mobile yang akan dibangun dapat dilihat pada Gambar 2. Tahapan identifikasi citra dimulai dengan proses pengambilan citra tanah untuk memperoleh data uji. Selanjutnya, citra dari data uji yang tidak ingin diproses dipotong. Jika citra digital yang diperoleh kurang baik, maka aplikasi akan meminta untuk melakukan akuisisi citra kembali. Jika citra digital yang diperoleh sudah baik, maka dilakukan ekstraksi ciri untuk tahap klasifikasi. Hasil klasifikasi akan dievaluasi sebagai tahap akhir dari tahapan ini.

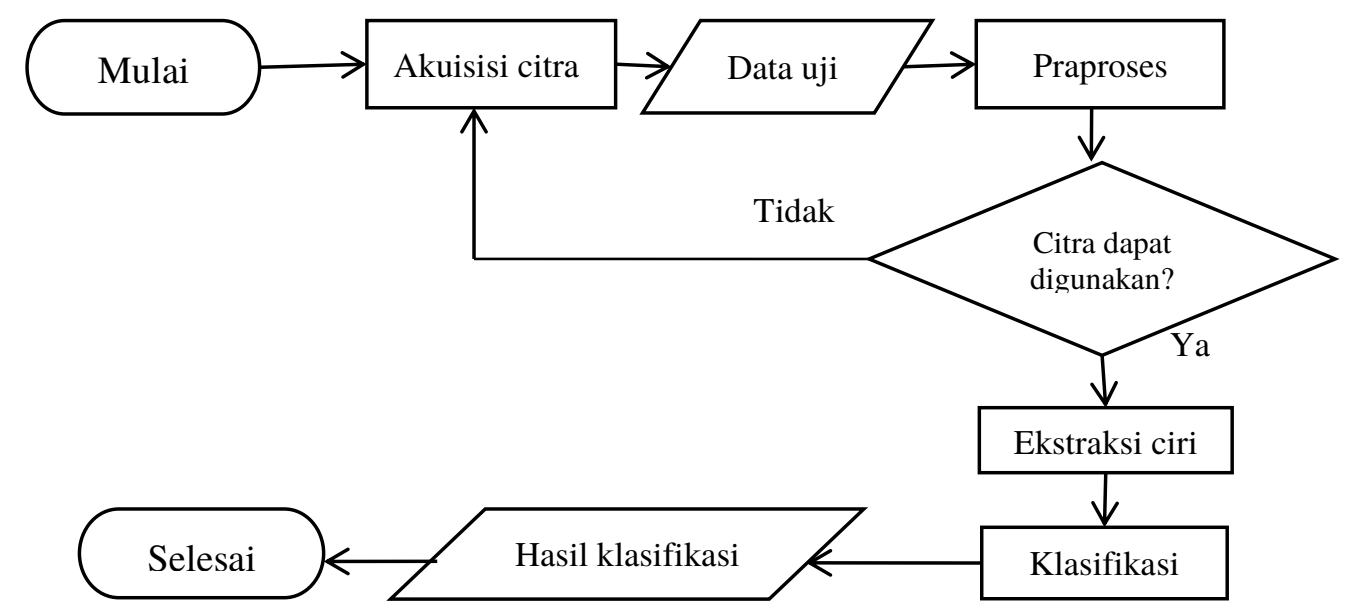

Gambar 2 Alur sistem untuk identifikasi citra

\section{Lingkungan Pengembangan}

Lingkungan pengembangan yang digunakan pada penelitian ini memiliki spesifikasi sebagai berikut.

- Perangkat lunak: OpenCV, Notepad++, Inkscape, Macromedia. dan XAMPP.

- Perangkat keras: smartphone Lenovo P780 (Android 4.2.1, kamera 8MP) dan notebook Samsung (spesifikasi prosesor AMD Vision A6, AMD Radeon grafik $2.70 \mathrm{GHz}$ ).

\section{HASIL DAN PEMBAHASAN}

Aplikasi yang dibangun yaitu aplikasi mobile berbasis Android yang bertujuan untuk mengidentifikasi warna tanah. Aplikasi ini diimplementasikan pada mobile device.

\section{Akuisisi}

Tahap ini dilakukan untuk mengambil citra digital dari buku MSCC sebagai data latih dan data uji. Hasil akuisisi citra tersebut menghasilkan sebanyak 47 data citra dari setiap skala warna hue. Buku MSCC memiliki 7 variasi nilai hue. Oleh karena itu, total data yang diperoleh yaitu 259 data citra, yang seluruhnya digunakan sebagai data latih. Data uji yang digunakan adalah 140 data citra, yang diambil secara acak dari data latih yang ada.

\section{Praproses}

Citra yang telah diakuisisi pada tahap sebelumnya dipotong sehingga menjadi berukuran 40×40 piksel. Proses pemotongan citra dari buku MSCC ditunjukkan pada Gambar 3.

\section{Ekstraksi Ciri}

Setiap citra hasil pemotongan menghasilkan 1600 piksel. Setiap piksel memiliki nilai red, green, dan blue (RGB) yang dikonversi menjadi nilai hue, value, dan chroma (HVC) antara 0-255. Frekuensi kemunculan nilai HVC ini ditampilkan dalam bentuk histogram 
warna. Perbandingan antara nilai value dan chroma yang ditunjukkan pada buku MSCC dengan rata-rata nilai value dan chroma hasil konversi dari data citra RGB untuk skala warna hue 5YR ditampilkan pada Gambar 4 dan Gambar 5. Gambar 4 menunjukkan bahwa koefisien determinasi untuk value cukup tinggi, yaitu $R=0.8688$, sedangkan Gambar 5 menunjukkan bahwa koefisien determinasi chroma cukup rendah, yaitu $R=0.1744$. Hal ini terjadi karena pada nilai chroma terdapat data pencilan yang membuat fungsi tidak linear, berbeda dengan nila value. Meskipun ekstraksi ciri untuk value dan chroma belum menunjukkan hasil yang memuaskan, namun perbandingan antara nilai value dan chroma dari buku MSCC dengan hasil pengukuran alat (Gambar 6) memiliki trend yang sama. Hal ini menunjukkan bahwa kedua komponen warna ini mungkin dapat diklasifikasikan pada penelitian selanjutnya. Untuk penelitian ini, klasifikasi hanya akan dilakukan untuk komponen warna hue saja.

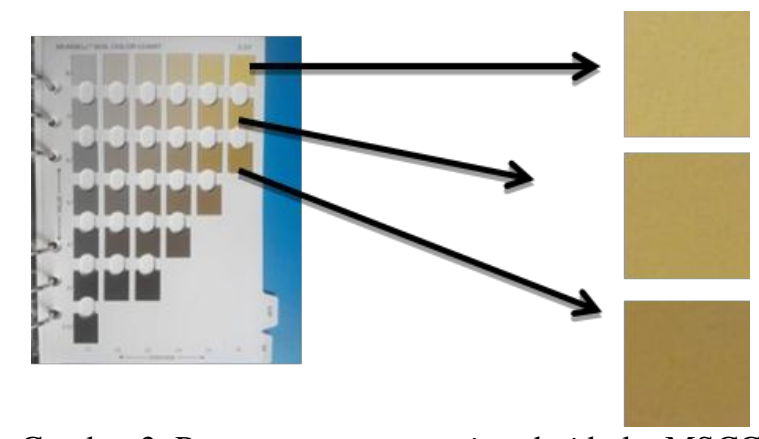

Gambar 3 Proses pemotongan citra dari buku MSCC

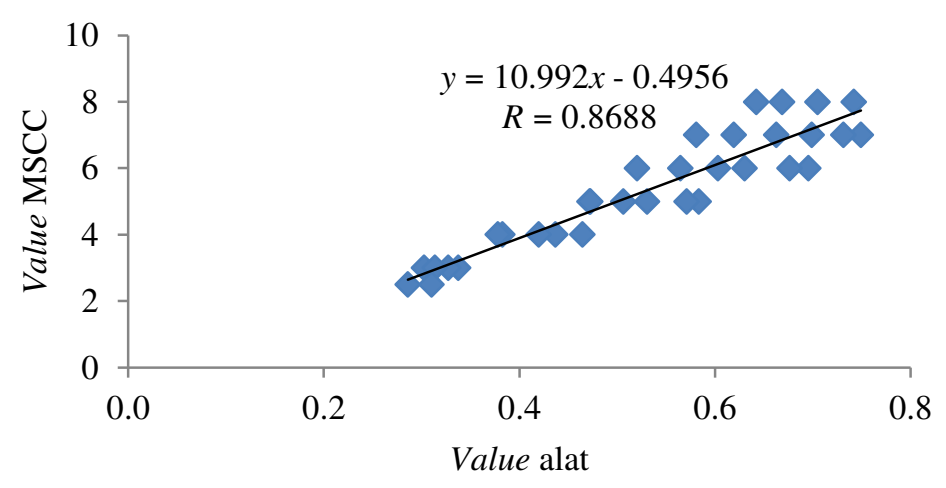

Gambar 4 Nilai value untuk skala warna hue 5YR

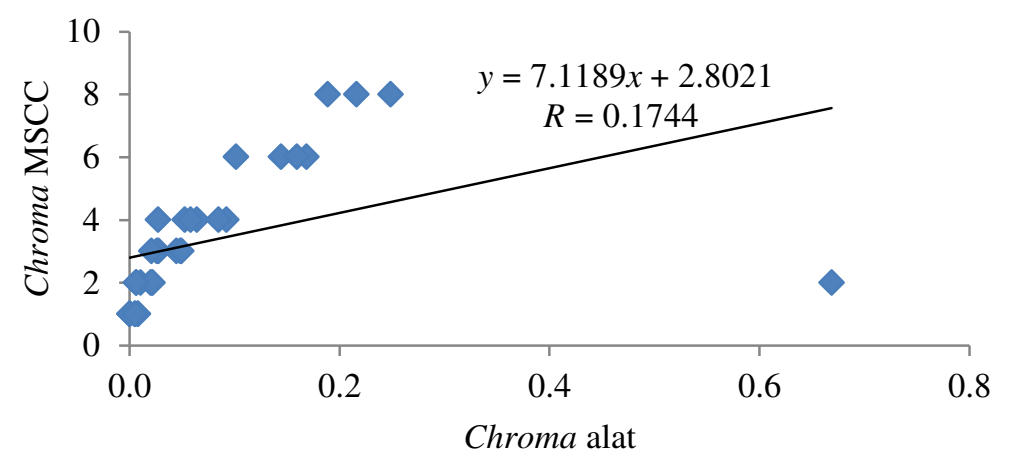

Gambar 5 Nilai chroma untuk skala warna hue 5YR 


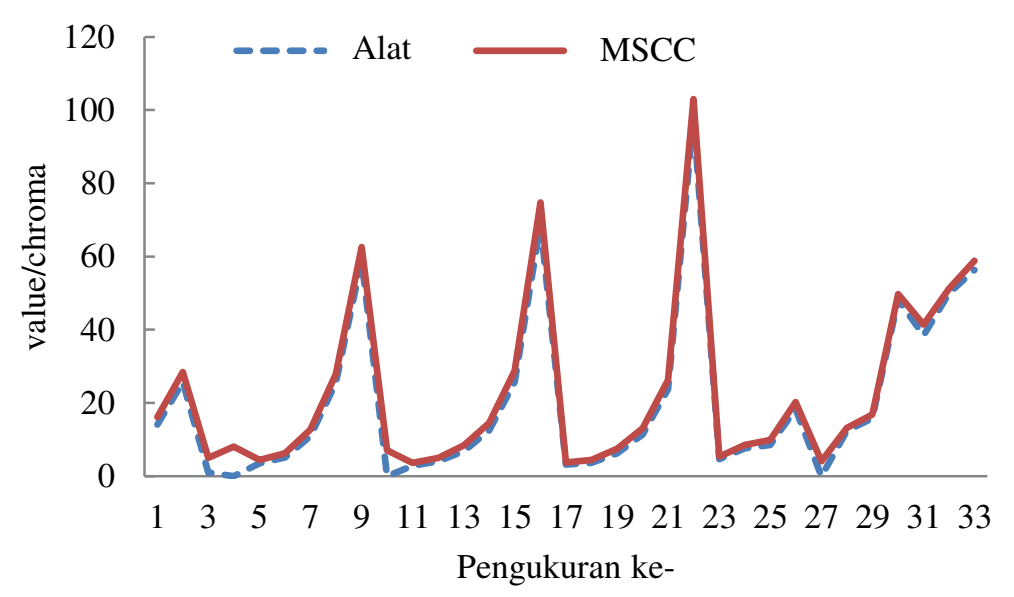

Gambar 6 Pola perbandingan antara value dan chroma untuk skala warna hue 5YR

Ekstraksi ciri untuk nilai hue ditunjukkan dalam bentuk histogram. Data histogram ini yang digunakan untuk membuat model klasifikasi dengan KNN pada PC. Walaupun pembuatan model klasifikasi dilakukan pada $\mathrm{PC}$, namun pengujiannya dilakukan pada mobile device tanpa harus terkoneksi dengan PC.

\section{Klasifikasi}

Hasil ekstraksi ciri adalah data histogram warna hue. Data ini digunakan untuk klasifikasi KNN dengan beberapa nilai $k$ yaitu 1, 2, 3, 4, 5, 6, dan 7. Penggunaan beberapa nilai $k$ yang berbeda ini menghasilkan nilai akurasi yang berbeda-beda seperti yang ditampilkan pada Tabel 1. Klasifikasi menggunakan KNN pada komponen warna hue menunjukkan nilai akurasi tertinggi pada nilai $k=5$ yaitu $45 \%$. Adapun akurasi tertinggi diperoleh pada skala warna 2.5YR. Visualisasi dalam bentuk grafik untuk data pada Tabel 1 ditunjukkan pada Gambar 7.

Tabel 1 Perbandingan nilai akurasi setiap komponen warna hue

\begin{tabular}{lccccrrrr}
\hline \multirow{2}{*}{ Nilai $k$} & \multicolumn{7}{c}{ Akurasi tiap skala warna MSCC } & \multirow{2}{*}{ Rataan } \\
\cline { 2 - 8 } & $2.5 \mathrm{Y}$ & $2.5 \mathrm{YR}$ & $5.5 \mathrm{Y}$ & $5.5 \mathrm{YR}$ & \multicolumn{1}{c}{$7.5 \mathrm{Y}$} & \multicolumn{1}{c}{ 10R } & 10YR & \\
\hline 1 & 20.00 & 100.00 & 10.00 & 5.00 & 30.00 & 10.00 & 40.00 & 30.71 \\
2 & 40.00 & 80.00 & 40.00 & 15.00 & 35.00 & 40.00 & 25.00 & 39.28 \\
3 & 40.00 & 75.00 & 30.00 & 20.00 & 0.00 & 5.00 & 15.00 & 26.42 \\
4 & 20.00 & 75.00 & 50.00 & 30.00 & 20.00 & 0.00 & 30.00 & 32.14 \\
5 & 30.00 & 50.00 & 45.00 & 50.00 & 55.00 & 40.00 & 45.00 & 45.00 \\
6 & 55.00 & 30.00 & 15.00 & 35.00 & 40.00 & 15.00 & 30.00 & 31.42 \\
7 & 25.00 & 40.00 & 40.00 & 40.00 & 20.00 & 20.00 & 50.00 & 33.57 \\
\hline Rataan & 32.85 & 64.28 & 32.85 & 30.71 & 28.57 & 18.57 & 33.57 & \\
\hline
\end{tabular}

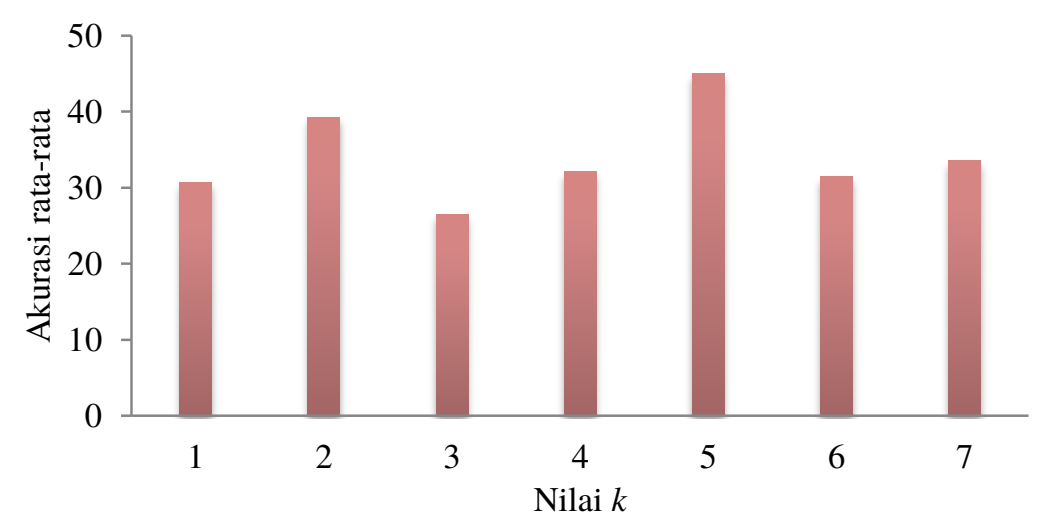

Gambar 7 Perbandingan akurasi rata-rata untuk setiap nilai $k$ 
Akurasi klasifikasi komponen warna hue yang rendah mungkin diakibatkan oleh tahapan praproses dan akuisisi citra yang kurang optimal. Optimisasi dapat dilakukan dengan beberapa cara, di antaranya dengan menggunakan data dari Google Play Store. Penggunaan data dari database yang telah ada akan meminimalisir pengaruh negatif dari penggunaan alat berresolusi rendah. Secara teoritis, informasi yang terkandung di dalam komponen warna hue adalah informasi mengenai keragaman warna, sehingga akurasi klasifikasi untuk hue seharusnya dapat menjadi lebih baik lagi.

Perlu diketahui bahwa penelitian ini merupakan tahap awal untuk penelitian atau pengembangan selanjutnya, yang juga akan mengklasifikasikan komponen warna value dan chroma. Jika penelitian selanjutnya berhasil, maka aplikasi ini akan memiliki nilai ekonomis yang tinggi, mengingat harga buku MSCC yang mencapai puluhan juta rupiah.

\section{SIMPULAN DAN SARAN}

Penelitian ini telah berhasil mengimplementasikan metode ekstraksi fitur histogram warna untuk masing-masing komponen warna pada model warna RGB dan HVC. Pada penelitian ini, klasifikasi warna tanah telah diimplementasikan dengan KNN untuk komponen warna hue. Hasil akurasi rata-rata tertinggi pada kelompok warna hue mencapai $45 \%$ pada nilai $k=5$. Akurasi tertinggi diperoleh pada skala warna hue 2.5YR.

Beberapa hal yang dapat dilakukan untuk memperbaiki aplikasi ini di antaranya: (1) melakukan praproses data tambahan, (2) menggunakan data soil color chart di Google Play Store sebagai data, (3) menggunakan metode hierarki dalam melakukan klasifikasi 7 kelompok warna hue, dan (4) mengembangkan aplikasi untuk kasifikasi nilai value dan chroma tanah.

\section{DAFTAR PUSTAKA}

Acharya T, Ray AK. 2005. Image Processing Principles and Applications. New Jersey (US): J Wiley.

Balai Penelitian Tanah. 2004. Petunjuk Teknis Pengamatan Tanah. Hidayat A, editor. Bogor (ID): Pusat Penelitian dan Pengembangan Tanah dan Agroklimat.

Boiman O, Shechtman E, Irani M. 2008. In defense of nearest neighbor based image classification. Di dalam: IEEE Conference on Computer Vision and Pattern Recognition; 2008 Jun 24-26; Anchorage, USA. hlm 1-8.

Ford A, Roberts A. 1998. Colour space conversion [internet]. [diunduh 2014 Feb 23]. Tersedia pada: http://www.poynton.com/PDFs/coloureq.pdf.

Gonzales RC, Wintz P. 1987. Digital Image Processing. 2nd ed. Boston (US): AddisonWesley.

Hardjowigeno S. 1985. Genesis dan Klasifikasi Tanah. Jakarta (ID): Akademi Prasindo.

Munsell AH. 2009. Munsell Soil Color Book. Grand Rapids (US): X-Rite.

Satyalesmana E. 2013. Aplikasi bagan warna daun untuk optimasi pemupukan tanaman padi menggunakan k-nearest neighbor [skripsi]. Bogor (ID): Institut Pertanian Bogor.

Soepardi G. 1983. Sifat dan Ciri Tanah. Bogor (ID): Institut Pertanian Bogor.

Song Y, Huang J, Zhou D, Zha H, Giles CL. 2007. Informative k-nearest neighbor pattern classification. Di dalam: Knowledge Discovery in Databases: PKDD. hlm 248-264.

Wahyudi. 2012. Robot hijau masih kuasai Indonesia [internet]. [diunduh 2014 Feb 23]. Tersedia pada: http://tekno.kompas.com/read/2012/12/18/09270540/2013.Robot.Hijau.Masih. Kuasai.Indonesia.

Walpole ER. 1992. Pengantar Statistika. Jakarta (ID): Gramedia. 